\title{
Esophageal Cancer: Epidemiological, Clinical and Histopathological Aspects over a 24-Years Period at Kamenge University Hospital, Bujumbura, Burundi
}

\author{
Rénovat Ntagirabiri ${ }^{*}$, Richard Karayuba², Gabriel Ndayisaba², Aline Nduwimana ${ }^{2}$, \\ Jean Claude Niyondiko ${ }^{2}$ \\ ${ }^{1}$ Gastroenterology Department, Kamenge University Hospital, Bujumbura, Burundi \\ ${ }^{2}$ Surgery Department, Kamenge University Hospital, Bujumbura, Burundi \\ Email: *ntagrenov@yahoo.fr
}

Received 6 March 2016; accepted 12 April 2016; published 15 April 2016

Copyright (C) 2016 by authors and Scientific Research Publishing Inc.

This work is licensed under the Creative Commons Attribution International License (CC BY). http://creativecommons.org/licenses/by/4.0/

\section{(c) (i) Open Access}

\begin{abstract}
Aim: There were no data about esophageal cancer in Burundi. The aim of the study was to highlight the epidemiological, clinical and histopathological aspects of the esophageal cancer. Method: A retrospective study over a 24-years period (from January 1988 to December 2011) was carried out at Kamenge university hospital, including patients with esophageal cancer. The cases were selected on basis of the histological evidence of the cancer. Results: A total of 34 cases were retrieved and included for analysis. Among them, 24 patients (70.5\%) were males. The esophageal cancer constituted $8.6 \%$ of digestive cancers over the period of the study. The average age was 50.9 years. It was revealed by dysphagia in 32 patients (94.1\%) and was concomitantly metastatic in 12 patients. The squamous cell carcinoma was 30 cases (88.2\%). 27 patients underwent a curative resection, but the outcome and prognosis were poor. In-hospital mortality and morbidity rates were respectively $\mathbf{8 . 8 \%}$ and $\mathbf{1 7 . 7 \%}$. Conclusion: The present study showed evidence that the esophageal cancer in our country had the same characteristics and distribution as well as in developing countries. It had a poor prognosis and efforts had to be done in the early cancer detection.
\end{abstract}

\section{Keywords}

Esophageal Cancer, Squamous Cell Carcinoma, Adenocarcinoma, Digestive Cancer

\footnotetext{
${ }^{*}$ Corresponding author.
} 


\section{Introduction}

The esophageal cancer is a primary malignant tumor with a poor prognosis. Its incidence varies according to the regions worldwide. The main risk factors are tobacco addiction, alcohol abuse and Barrett's esophagus that constitute a precancerous lesion associated with the gastro-esophageal reflux disease (GERD) [1] [2]. The esophageal cancer problem has also been investigated at the cellular and immunological levels and mass cytological surveys allow many cases of early cancer to be detected and treated [3]. Particularly in Sub-Saharan Africa, the esophageal cancer constitutes a great problem of public health for it is almost diagnosed at the tardy stage [4][6].

In Burundi, data about the esophageal cancer are missing. Indeed, there is not any cancer registry in the country. In addition, there is not so far any national policy to regulate tobacco and alcohol consumption despite that they constitute risk factors of a number of diseases including esophageal cancer. Also, people have traditionally subscribed to the belief that alcohol is a social link and its abuse becomes common. GERD is also frequent, about 35\% in Burundi [7] [8]. All these facts may contribute to increase the incidence of this type of cancer. So far, there has been no study concerning the esophageal cancer in Burundi. Thus, it seems relevant to carry out a first study designed to highlight the epidemiological, clinical and histopathological aspects of the esophageal cancer over a 24 years period.

\section{Patients and Method}

Site of the study: The study was carried out at Kamenge university hospital, the public and national tertiary referral hospital, with a capacity of 2275 admissions per year in the department of surgery. It is also the one hospital with a histopathological laboratory in Burundi.

Study design: A retrospective study over a 24-years period, designed to highlight the age, sex, clinical features, therapeutic approaches and histopathological subtypes of patients with esophageal cancer in Kamenge university hospital. The study population consisted of all patients attending medical care's at Kamenge university hospital since January 1988 to December 2011 for esophageal cancer. We included only patients with esophageal cancer diagnosed on basis of the histological evidence. Cases of esophageal cancer that have been histologically confirmed were retrieved from medical files and included for the study analysis. Patients with histological data missing or data outliers were excluded. Epidemiological variables like age, sex, and clinical features, therapeutic approaches and histopathological subtypes were collected initially in a specialized data collection form. Data management and analysis were performed using the statistical package for social sciences (SPSS) 10.0 for window version. Proportions are given with their confidence interval 95\% (CI); $p$ value $<0.05$ was considered as statistically significant.

Ethical consideration: The ethics committee of Kamenge university hospital approved the study.

\section{Results}

During the period of the study, a total number of 34 cases of esophageal cancer were selected, either $8.7 \%$ (CI: $6 \%-12 \%$ ) of 391 cases of digestive cancer retrieved over that period. The annual frequency was estimated to 1.4 per year. As far as gender was concerned, 24 patients (70.5\% CI: 53\% - 83\%) were males and 10 patients were females (29.5\% CI: $17 \%$ - 47\%), sex-ratio: 2.4 . The average age was 50.1 years with the extremes of 29 years and 70 years. There was no difference of age between males and females $(p>0.05)$.

Concerning risk factors, the alcohol abuse was avowed by 17 patients (50\% CI: 34\% - 66\%), tobacco addiction by 14 patients (29.4\% CI: 16\% - 46\%) and GERD was retrieved among 16 patients (47.1\% CI: 31\% - 63\%).

Clinically, 32 patients (94.1\% CI: 80\% - 98\%) had dysphagia, 10 patients had epigastric pain, 2 patients had a chest pain. In addition, 16 patients (47\% CI: 31\% - 63\%) had a weight loss of more than $5 \mathrm{~kg}$ in the 3 previous months and 8 patients (23.5\% CI: 12\% - 40\%) had a Virchow's node. A total of 24 patients (70.6\% CI: 53\% $83 \%$ ) attended medical care within 6 months since the beginning of the symptoms. Those descriptions appear in Table 1.

All patients underwent upper digestive endoscopy. Macroscopically, 20 patients (58.8\% CI: 42\% - 74\%) had a burgeoning tumor, 10 patients (29.4\% CI: 16\% - 46\%) an ulcero-burgeoning tumor and 4 patients (11.8\% CI: $4 \%$ - 27\%) had an ulcero-infiltrating tumor. There was a complete stenosis among 7 patients (20.9\% CI: $10 \%$ $39 \%)$. The tumor' localizations were: 8 cases (23.5\% CI: $12 \%-40 \%)$ in the superior esophagus, 7 cases (20.9\% 
Table 1. Epidemiological and clinical aspects of esophageal cancer in Bujumbura.

\begin{tabular}{ccc}
\hline Variables & Number & Percentage \\
\hline Epidemiological features & & 70.5 \\
Males & 24 & 64.7 \\
Rural residence & 22 & 70.5 \\
Consultation within 6 months & 24 & 94.1 \\
Clinical features & & 47.1 \\
Dysphagia & 32 & 29.4 \\
Weight loss & 16 & 23.5 \\
Epigastric pain & 10 & 23.5 \\
Virchow's node & 8 & 11.8 \\
Node metastasis & 8 & 8.8 \\
Lung metastasis & 4 & 3 \\
Hepatic metastasis & & 3 \\
\hline
\end{tabular}

CI: $10 \%$ - 39\%) in the middle esophagus and 19 cases (55.9\% CI: 39\% - 71\%) in the lower esophagus.

On imaging, 8 patients had nods metastasis, 4 patients had lung metastasis and 3 patients had also liver metastasis.

On histopathology, 30 patients (88.2\% CI: 73\% - 95\%) had a squamous cell carcinoma (well differentiated in 22 cases) and 4 patients (11.8\% CI: 4\% - 27\%) had an adenocarcinoma. The macroscopical and histopathological aspects are detailed in Table 2.

As surgical approach and outcomes, a curative excision was done for 27 patients (79.4\% CI: 63\% - 90\%) while 7 patients underwent a palliative gastrostomy for feeding. In-hospital mortality rate was 8.8\% (CI: 3\% 23\%) and morbidities were mainly constituted by infection for 2 patients (5.9\% CI: 1\% - 20\%) and respiratory failure for 4 patients (11.8\% CI: 4\% - 27\%).

\section{Discussion}

The present study is the first study in Burundi, highlighting the age, sex, clinical features, therapeutic approach and histopathological subtypes of the esophageal cancer. The Kamenge university hospital was the best situated center for such study. Indeed, it is the one public and national tertiary referral hospital with a histopathological laboratory in Burundi. In addition, there is no cancer registry in our country. Nevertheless, the single center aspect of the present study seems to be a weakness, but it was not possible to extend the study in other centers, as subjects were selected on the basis of the histopathological evidence of cancer. In fact, the single histopathological laboratory in Burundi is located in Kamenge university hospital. The limitation of this study is the common drawback associated with the use of a retrospective method. Consequently, we failed to retrieve data to establish the one or the five years survival rates of the patients. Indeed, after hospital discharge, most of the patients return in rural area and continue with traditional medication, with seems to be affordable for them.

Therefore, the first important finding in our study is that the distribution of esophageal cancer among our population is similar to other studies in Sub-Saharan Africa. Indeed, our findings showed that the esophageal cancer constitutes $8.6 \%$ of digestive cancer and that it affects most frequently male population. The same is in Rwanda, the neighboring country with almost the same culture and ethnical groups, where the esophageal cancer occupies $9.4 \%$ of digestive cancers [9]. Furthermore, a patchy study over a two-year period (1988-1989) about digestive cancers in Bujumbura showed that the esophageal cancer constitutes the $4^{\text {th }}$ digestive cancer after the gastric, the liver and the colon cancer [10]. However, authors of that study failed to make an epidemiological analysis because of a small number of esophageal cancer cases (only 8 cases) [10]. Speaking of the situation prevailing in the Sub-Saharan Africa, esophageal cancer affects mostly males in Senegal (Dakar) with an average age of 49years [11]. In Mali, the authors found a average age of 59 years [4]. Similarly with our study, a number of African authors found an annual frequency of esophageal cancer inferior to 5cases per year [6] [12] [13]. In 
Table 2. Macroscopical and histopathological aspects of esophageal cancer in Bujumbura.

\begin{tabular}{ccc}
\hline Variables & Number & Pourcentage \\
\hline Macroscopical aspects & & 58.8 \\
Burgeoning tumor & 20 & 29.4 \\
Ulcero-burgeoning tumor & 10 & 11.8 \\
ulcero-infiltrating tumor & 4 & 88.2 \\
Histopathological aspects & & 11.8 \\
Squamous cell carcinoma & 30 & 4 \\
Adenocarcinoma & & 4 \\
\hline
\end{tabular}

general, studies about esophageal cancer in the Sub-Saharan African region seem to be patchy with small samples and concerned mainly in-hospital population. The lack of modern diagnostic tool, the small number of specialized centers and poverty constitute the main challenge in our region and could be a source of underestimation of the cancer.

The second important finding is that alcohol and tobacco abuse, as major risk factors, were implicated in 50\% of cases in our study. Thus, that finding constitutes a great argument for the health authority in our country to regulate alcohol and tobacco consumption among population, particularly young people, in order to limit their unhealthy consequences. Also, it could be used as evidence in motivating a decree about alcohol and tobacco consumption in our country like it is done in some western countries. It seems to be a big challenge because people in Burundi have traditionally subscribed to the belief that alcohol constitutes a social link and its abuse becomes common, although it is one of the documented risk factors [1] [2].

The third important finding in our study is that the carcinoma was the most frequent type of esophageal cancer. It is a very aggressive histological type with a poor prognosis as well as in developed countries [14] [15]. Also, our study population consulted late. Consequently, the prognosis was poor. The same situation is prevailing in a number of the Sub-Saharan African studies [4]-[6] [11]. Mass education about early detection and prevention of cancer seems to be crucial in our country.

\section{Conclusion}

The present study showed evidence that the esophageal cancer in our country had the same characteristics and distribution like elsewhere in developing countries. The most frequent histopathological type was the squamous cell carcinoma. The diagnosis was delayed and the prognosis was poor. Efforts had to be done for prevention of risk factors and early detection of the disease.

\section{Authors' Contributions}

Rénovat Ntagirabiri designed the study and participated in all the steps of the study. Other authors contributed in data collecting, analysis and literature review. All authors participated in the study. They all approved the final version.

\section{Competing Interest}

All authors declare no competing interests.

\section{References}

[1] Hongo, M., Nagasaki, Y. and Shoji, T. (2009) Epidemiology of Esophageal Cancer: Orient to Occident. Effects of Chronology, Geography and Ethnicity. Journal of Gastroenterology and Hepatology, 24, 729-735. http://dx.doi.org/10.1111/j.1440-1746.2009.05824.x

[2] Zheng, S., Vuitton, L., Sheyhidin, L., Vuitton, D.A., Zhang, Y. and Lu, X. (2010) Northwestern China: A Place to Learn More on Oesophageal Cancer. Part One: Behavioural and Environmental Risk Factors. European Journal of Gastroenterology \& Hepatology, 22, 917-925. http://dx.doi.org/10.1097/MEG.0b013e3283313d8b

[3] Yang, C.S. (1980) Research on Esophageal Cancer in China: A Review. Cancer Research, 40, 2633-2644. 
[4] Maïga, Y.M., Diallo, G., Dembele, M., Ndiaye, M., Ongoiba, N., Sanogo, Z., Yena, S. and Traoré, H.A. (2002) Cancer de l’œsophage: Aspects épidémiologiques, cliniques et pronostiques. Acta Endoscopica, 32, 455-459. http://dx.doi.org/10.1007/BF03020579

[5] Bagny, A., Bouglouga, O., Djibril, M.A., M’ba, K.B., Kaaga, L., Lawson A.L., Amégbor, K., Darré, T. and Redah, D. (2012) Cancer de l’oesophage: Aspect épidémiologique, clinique et histologique au CHU Campus de Lomé (Togo). Journal Africain d'Hépato-Gastroentérologie, 6, 24-27. http://dx.doi.org/10.1007/s12157-011-0339-2

[6] Harouna, Y.D., Illo, A., Assoumane, I. and Onouha, C. (2008) Cancers de l'œsophage au Niger: Aspects épidémiologiques, cliniques à propos de 36 cas. Médecine d'Afrique Noire, 55, 235-239.

[7] Ntagirabiri, R., Mumana, A., Baransaka, E., Niyonzima, S. and Ndayishimiye, H. (2013) Gastro-Esophageal Reflux Disease among People Consulting in Bujumbura. J. Afr. Hépatol. Gastroentérol, 7, 204-207. http://dx.doi.org/10.1007/s12157-013-0496-6

[8] Ntagirabiri, R., Niyonzima, S., Mumana, A.L. and Ndabaneze, E. (2013) Gastro-Esophageal Reflux Disease in African Young Adult: Case of Burundian University Students. Journal Africain d'Hépato-Gastroentérologie, 7, $192-195$. http://dx.doi.org/10.1007/s12157-013-0489-5

[9] Ndahindwa, V., Ngendahayo, L. and Vyankandondera, J. (2012) Aspects épidémiologiques et anatomopathologiques des cancers dans les centres hospitaliers universitaires (chu) du rwanda. Revue Médicale Rwandaise, 69, 40-49.

[10] Kadende, P., Engels, D., Ndoricimpa, J., Ndabaneze, E., Habonimana, D., Marerwa, G., Bigirimana, V., Bazira, L. and Aubry, P. (1990) Les cancers digestifs au Burundi: Premiers résultats d’une enquête menée à Bujumbura. Médecine d'Afrique Noire, 37, 552-562.

[11] Dia, D., Bassène, M.L., Ndiaye-Bâ, N., Halim, A., Diallo, S., Fall, S., Diouf, M.F., Mbengue, M. and Diouf, M.L. (2011) Endoscopic Features of Esophageal Cancer in Dakar, Senegal: Study of 76 Observations. Médecine Tropicale, 71, 286-288.

[12] Sawadogo, A., Ilboudo, P.D., Durand, G., Peghini, M., Branquet, D., Sawadogo, A.B. and Ouedraogo, I. (2000) Epidémiologie des cancers du tube digestif au Burkina Faso: Apport de 8000 endoscopies effectuées au centre hospitalier Sanou sourou (CHSS) de Bobo dioulasso. Médecine d'Afrique Noire, 7, 342-345.

[13] Pindiga, H.U., Akang, E.E., Thomas, J.O. and Aghadiuno, P.U. (1997) Carcinoma of the Esophagus in Ibadan. East African Medical Journal, 7, 307-310.

[14] Kelsen, D.P., Ginsberg, R., Pajak, T.F., Sheahan, D.G., Gunderson, L., Mortimmer, J., Estes, N., Haller, D.G., Ajani, J., Kocha, W., Minsky, B.D. and Roth, J.A. (1998) Chemotherapy Followed by Surgery versus Surgery Alone for Localized Esophageal Cancer. The New England Journal of Medicine, 339, 1979-1984. http://dx.doi.org/10.1056/NEJM199812313392704

[15] Ruol, A., Castoro, C., Portale, G., Cavallin, F., Sileni, V.C., Cagol, M., Alfieri, R., Corti, L., Boso, C., Zaninotto, G., Peracchia, A. and Ancona, E. (2009) Trends in Management and Prognosis for Esophageal Cancer Surgery. Archives of Surgery, 144, 247-254. http://dx.doi.org/10.1001/archsurg.2008.574 